\title{
Pengaruh Verbal Abuse, Kualitas Komunikasi Orang Tua dan Konformitas Teman Sebaya Terhadap Perilaku Agresif Remaja
}

\author{
Nazhifah \\ Program Magister Ilmu Komunikasi \\ Fakultas Ilmu Sosial dan Politik, Universitas Sebelas Maret \\ Email: nazifahh@gmail.com
}

\begin{abstract}
Verbal abuse communication is a phenomenon that occurs in society, provides tremendous impact in the long-term behavior of children. With the lack of attention and communication between children and parents, it could also contribute to the change of children's behavior; the children-parents disharmony will greatly influence the development of children both physically and psychologically. This study aims to observe the influence of verbal abuse communication of parents, communication quality and conformity of same-age friends in affecting aggressive behavior. This study uses social learning theory and is supported by several supporting theories in order to assist in clarifying the relation between variables; parental rejection theory, and social comparison theory. Method of the study is quantitative. Data collection technique employed is questionnaire with 99 teenagers at Simpang Tiga Pekanbaru as sample through random sampling technique. The results showed that an influence of the verbal abuse communication of parents toward the aggressive behavior of 0,575; communication quality of parents toward the aggressive behavior of 0,522; in the conformity of same-age friends toward the aggressive behavior of 0.677 in the strong category. The total influence of verbal abuse communication of parents, communication quality of parents and conformity of sameage friends toward the aggressive behavior is 0.478 in the moderate category. Thus, the four variables of the study provide positive effect in influencing aggressive behavior.
\end{abstract}

Keywords: Verbal Abuse, Communication quality, conformity, aggressive behavior

\begin{abstract}
Abstrak
Verbal abuse merupakan perilaku negatif yang tanpa disadari memberikan dampak yang luar biasa pada perilaku anak dalam jangka panjang. Kurangnya perhatian dan komunikasi antara anak dan orang tua dapat memberikan perubahan pada perilaku anak, ketidakharmonisan diantara keduanya banyak mempengaruhi perkembangan anak baik fisik maupun psikis. Tujuan penelitian ini adalah untuk melihat pengaruh komunikasi verbal abuse, kualitas komunikasi orang tua dan konfomritas teman sebaya dalam mempengaruhi perilaku agresif. Penelitian ini menggunakan teori social learning theory dan didukung dengan beberapa teori pendukung untuk memperjelas hubungan antar variabel, diantaranya teori parental rejection, dan teori social comparison. Metode yang digunakan adalah kuantitatif. Teknik pengumpulan data:kuesioner, sampel sebanyak 99 responden remaja di Kelurahan Simpang Tiga Pekanbaru, dengan teknik random sampling. Hasil penelitian menunjukkan pengaruh komunikasi verbal abuse orang tua terhadap perilaku agresif sebesar 0,575 ; kualitas komunikasi orang tua terhadap perilaku agresif sebesar 0,522 dan pengaruh konformitas teman sebaya terhadap perilaku agresif sebesar 0,677 . Total pengaruh komunikasi verbal abuse orang tua, kualitas komunikasi orang
\end{abstract}


tua dan konformitas teman sebaya terhadap perilaku agresif sebesar 0,478. Keempat variabel dalam penelitian ini memberikan pengaruh positif dalam mempengaruhi perilaku agresif.

Kata kunci : Verbal Abuse, Kualitas komunikasi, konformitas, perilaku agresif

\section{Pendahuluan}

Zaman sekarang, cara orang tua berkomunikasi dengan anak, agar anak patuh dan nurut dilakukan dengan cara yang salah. Walaupun perkataan ataupun kalimat yang disampaikan seolah-olah adalah hal yang biasa mereka katakan kepada anak dengan memberikan pelabelan atau panggilan nama anak dengan panggilan yang tidak disenangi anak, melecehkan kemampuan anak di depan saudaranya, membentak dengan kasar atau pun memaki dengan kalimat atau kata-kata yang kasar itu merupakan bentuk dari tindakan komunikasi verbal abuse.

Kekerasan verbal atau dikenal dengan istilah Verbal abuse yakni berupa bagian dari tindakan komunikasi dengan menggunakan ucapan atau kata-kata kasar ataupun kekerasan secara verbal yang dilakukan orang tua pada anak (Charles,1998). Kementerian Pemberdayaan Perempuan dan Perlindungan Anak (PPPA), bahwa kekerasan anak dan perempuan di Indonesia jumlahnya lebih dari 150 ribu kasus sepanjang 2016 (Nugroho,2016). Sebanyak 60\% merupakan korban kekerasan ringan, berupa kekerasan verbal atau caci maki, sedangkan $40 \%$ sisanya mengalami kekerasan fisik hingga seksual (Solihin,2005).

Harian Tempo juga menyebutkan bahwa tingkat kekerasan terhadap anak di Indonesia masih tergolong tinggi. Menurut Ketua Komisi Perlindungan Anak Indonesia (KPAI) banyak dari pelaku kekerasan terhadap anak ini justru adalah orang tuanya sendiri. Setiap tahun angka kekerasan terhadap anak mencapai 3.700, dan rata-rata terjadi 15 kasus setiap harinya. (Tempo, 26 April 2016)

Kekerasankomunikasiverbalpalingbanyak didapat oleh anak yang dilakukan oleh orang tua (Sirotnak,2001). Sebuah survei menemukan bahwa pelecehan verbal terjadi di rumah dengan anak-anak dari semua usia dan pelecehan verbal biasanya terjadi pada remaja yang tinggal di rumah. Pada masa remaja, pelecehan verbal memiliki dampak seperti kecemasan, penarikan diri, rendah diri, berperilaku menyimpang, dan nilai sekolah yang buruk (Ferguson, 2009; Kaya, Gidycz, Warkentin, Loh, \& Weiland, 2005; Solomon \& Serres, 1999; Vissing et al., 1991) dalam (Jennifer Loh, 2015).

Salah satu faktor penyebab terjadinya perilaku agresif pada anak adalah adanya faktor peran dengan meniru perilaku orang lain (Mu'tadin, 2004). Pengasuhan dan pendidikan anak dalam lingkungan keluarga merupakan 'instansi' pertama dalam proses perkembangan dan pendidikan anak serta remaja (Handayani. dkk, 2000).

Perubahan perilaku pun dapat pula terjadi akibat kurangnya perhatian yang diberikan orang tua kepada anknya, sehingga lama-kelamaan jika kondisi ini tanpa disadari dapat menjadi penghalang dan kerenggangan hubungan orang tua dengan anak serta menyebabkan terganggunya interaksi diantara keduanya. Menurut McAdams, sebagian besar penelitian menunjukkan bahwa kurangnya pemantauan, perhatian dan komunikasi dari orang tua kepada anak memberikan kontribusi besar pada perubahan perilaku anak (Knorth,dkk, 2007).

Selain itu, Pengaruh lingkungan sosial yakni teman sebaya memegang peranan yang cukup besar. Karena itulah anak-anak atau remaja berusaha untuk menyesuaikan perilakunya agar sesuai dengan aturan dalam kelompok. Konformitas akan semakin kuat jika 
seorang remaja memiliki kecenderungan yang kuat untuk berperilaku sama dengan kelompok (Zebua \& Nurdjayanti, 2001).

Remaja sering menghabiskan banyak waktu untuk berkumpul dan saling berkomunikasi dan berinteraksi dengan kelompok atau teman sebaya. Hal ini dapat terlihat pada penelitian Csikzentmihalyi \& Larson (1984) dalam Colins (1995) yang menyatakan dalam hasil penelitiannya bahwa, rata-rata remaja menghabiskan waktu sekitar 24 jam dalam seminggu bersama dengan teman sebaya mereka diluar sekolah. Sedangkan Chiazza, T (2008) dalam penelitiannya menemukan bahwa 48,6\% menghabiskan 10 jam atau lebih setiap minggunya tanpa pengawasan orang dewasa, 21,9\% 7- 9 jam, 20\% 4 - 6 jam, $1-3$ jam 7,6\% dan selebihnya tidak pasti.

Perilaku agresif atau perilaku kekerasan yang muncul pada remaja dapat berupa fisik dan verbal. Perilaku agresif berupa verbal seperti kata-kata mengejek, mengumpat dan berkata kotor serta dapat pula perilaku agresif berupa fisik seperti menggigit, mencubit, dan menendang (Buss dan Perry, 1992).

Berdasarkan data yang dimiliki oleh Badan Pusat Pelayanan Terpadu Pemberdayaan Perempuan dan Anak (P2TP2A) Provinsi Riau, telah menangani 646 kasus pengaduan kekerasan perempuan dan anak dalam kurun waktu lima tahun terakhir. Pada tahun 2014 jumlah kasus kekerasan terhadap anak sekitar 20-25 kasus, lalu di tahun 2015 meningkat menjadi 40 kasus, dan 2016 naik menjadi 53 kasus terhadap anak, baik itu kasus penganiayaan, kekerasan fisik dan mental. Dari 12 kabupaten/kota, kota Pekanbaru merupakan daerah terbanyak kejadian kasus kekerasan terhadap anak mencapai 431 kasus dalam tiga tahun terakhir (Arni, 2015).

Penelitian ini mengambil area di Kelurahan Simpang Tiga, Kecamatan Bukit Raya Kota Pekanbaru, karena berdasarkan pengamatan diawal menunjukkan bahwa 5 dari 6 anak sekitar $70 \%$ di daerah ini pernah mendapatkan kata-kata kasar maupun kalimat yang bersifat mengancam dari orang tua. Berdasarkan hasil wawancara dari beberapa orang tua (24 Desember 2016) bahwa orang tua menganggap hal biasa memarahi anak-anaknya yang terkadang agak sedikit kasar dengan maksud agar anak dapat di atur, nurut dan patuh.

Daerah kawasan Kelurahan Simpang Tiga, berdasarkan observasi awal banyak remaja yang suka berkumpul di warung-warung, simpang-simpang jalan, dan di pos-pos ronda, disana mereka sering main domino, merokok dan bercanda tawa serta saling berkomunikasi dengan kata-kata yang kurang enak di dengar atau kurang sopan. Perilaku tersebut pernah sampai mengganggu ketentraman masyarakat yang sedang istirahat malam.

Menurut Polresta Pekanbaru, daerah kecamatan Bukit Raya merupakan salah satu daerah yang rawan terjadi gangguan keamanan dan ketertiban masyarakat yang dilakukan oleh remaja, diantaranya terdapat 243 kasus yang tersebar terutama di Kelurahan Simpang Tiga (Hadi, 2015). Dibarengi dengan tingkat partisipasi sekolah remaja yang menurun pada usia 7-12 tahun. Tahun 2015-2016 sebanyak 99,51 menjadi 98,34 (BPS Kota Pekanbaru, 2016). Populasi remaja di Kecamatan Bukit Raya memiliki jumlah ke-3 terbanyak di Kota Pekanbaru dengan 106.616 remaja dan khususnya untuk di Kelurahan Simpang Tiga, memiliki jumlah remaja terbanyak dengan 14.576 remaja (BPS Kota Pekanbaru, 2016).

Pada tahun 2014-2015 di Kota Pekanbaru juga terdapat kasus kekerasan yang dilakukan remaja yang bergabung dalam satu kelompok geng motor. Tahun 2014 tercatat sebanyak 30 kasus pidana yang dilakukan geng motor; Januari-Mei tahun 2015 tercatat 10 kasus. Tindakan kriminal yang mereka lakukan antara lain pencurian dengan kekerasan, pengrusakan, penganiayaan,hingga pemerkosaan. Kasat Reskrim Polresta Pekanbaru mengatakan banyak remaja siswa pelajar tingkat SMP dan SMA menjadi anggota geng motor yang sudah didoktrin untuk melakukan tindak kriminal seperti penjambretan, penodongan, pencurian,penganiayaan berat, perusakan dan 
pengancaman (beritasatu.com, 05 November, 2015) Berdasarkan kejadian tersebut dapat disimpulkan bahwa remaja cenderung mudah terpengaruh oleh lingkungan untuk melakukan perilaku agresif.

Terdapat beberapa kasus menyimpang pada remaja yang terjadi di Kelurahan Simpang Tiga, berdasarkan data dari Polres Kecamatan Bukit Raya 2017, bahwa kasus kriminalitas terbesar adalah penganiayaan yaitu sebesar 34 kasus, diiukuti kebut-kebutan di jalan sebesar 25 kasus. Selebihnya seperti narkoba, pengeroyokan, penghinaan, KDRT, perbuatan tidak menyenangkan, pengrusakan fasilitas umum, percobaan pencurian dan pengancaman kurang dari dari 10 kasus.

Dari hasil wawancara (24 Januri 2017), 8 anak yang dipilih secara acak mengenai kurangnya kualitas komunikasi orang tua. Bahwa 5 dari anak atau remaja mengatakan, mereka merasa kurang menyenangkan untuk bercerita atau curhat dengan orang tua dikarenakan sikap-sikap yang dimiliki oleh orang tua yang cenderung mengarah kepada hal yang negatif tentang kehidupan remaja. Dan 7 dari mereka kurang berminat untuk terlalu terbuka dengan orang tua selain dikarenakan alasan diatas, kesibukan yang dimiliki orang tua yang pada akhirnya menyebabkan kurangnya kedekatan dan keintiman diantara orang tua dan anak. Kurangnya kualitas komunikasi yang terjalin antara orang tua dan anak sehingga keefektifan komunikasi di dalam keluarga akan berpengaruh dengan perubahan sikap dan perilaku anak, salah satunya muncul kecenderungan anak untuk berperilaku menyimpang.

Research ini menguji pengaruh komunikasi verbal abuse orang tua terhadap perilaku Agresif dan menguji pengaruh kualitas komunikasi terhadap perilaku agresif. Serta akan melihat pengaruh konformitas teman sebaya terhadap perilaku agresif. Lebih lanjut, penelitian ini juga bermaksud menguji pengaruh komunikasi verbal abuse orang tua, kualitas komunikasi orang tua dan konformitas teman sebaya secara bersama-sama terhadap perilaku Agresif.
Rosenthal (1998) menyatakan komunikasi Verbal Abuse berupa tindakan komunikasi yang berisi ancaman, perkataan kasar, atau menghina kemampuan anak yang dilakukan secara terusmenerus. Berkowitz (2003) mendefinisikan perilaku verbal abuse sebagai suatu bentuk perilaku atau aksi kekerasan yang diungkapkan untuk menyakiti orang lain, perilaku kekerasan verbal dapat berbentuk umpatan, celaan atau makian, ejekan, fitnah dan ancaman melalui kata-kata.

Bentuk-bentuk Komunikasi Verbal Abuse Terdapat empat bentuk-bentuk dari komunikasi verbal abuse menurut Tower (2005) yaitu: (1). Membentak, yaitu memarahi dengan suara keras, seperti ; menghardik, adalah mencaci dengan perkataan keras., menghakimi, adalah mengadili atau berlaku sebagai hakim, mengumpat, adalah mengeluarkan kata-kata kotor ; (2) Memaki, yaitu mengucapkan kata-kata keji, tidak pantas, kurang baik dalam menyatakan kemarahan atau kejengkelan, seperti; mencela, yaitu menghina dengan terang-terangan, menyumpahi, adalah mengeluarkan kata-kata kotor untuk mengambil sumpah; (3). Memberi julukan negatif atau melabel, yaitu memberi tanda identifikasi melalui bentuk kata-kata, seperti mengklasifikasi, penggolongan, pengelompokkan berdasarkan sesuatu yang sesuai dengan kelasnya, ; (3) Mengecilkan dan melecehkan kemampuan anak, yaitu membuat jadi rendah keberadaan anak, antara lain : mengabaikan, adalah melalaikan, menyia-nyiakan, menyampingkan, adalah menyingkirkan kearah pinggir, menyepelekan, adalah memandang remeh, menistakan, adalah hina, tercela.

Kekerasan yang dialami oleh anak dapat berdapak pada fisik maupun psikologis anak. Huberty (2012) menegaskan bahwa Verbal abuse sangat berpengaruh pada anak terutama perkembangan psikologisnya, berikut dampakdampak psikologis akibat kekerasan verbal pada anak : (1) Mengganggu perkembangan sehingga anak yang mendapatkan perlakuan salah secara terus menerus akan memiliki citra diri yang negatif. Hal tersebut mengakibatkan 
anak tidak mampu tumbuh sebagai pribadi yang penuh percaya diri; (2) Konsep diri yang rendah, dimana anak yang sering mendapatkan perlakuan salah akan berpengaruh terhadap konsep dirinya, anak akan merasa dirinya jelek, tidak dicintai, tidak dikehendaki, muram, dan tidak bahagia, tidak mampu menyenangi aktifitas,anak biasanya menjadi kurang percaya diri, atau sebaliknya menjadi pemberontak. (3) Agresif, komunikasi yang negatif mempengaruhi perkembangan otak anak, karena anak yang selalu dalam keadaan terancam sulit bisa berpikir panjang, tidak bisa memecahkan masalah yang dihadapinya, hal ini berkaitan dengan bagian otak yang bernama korteks, pusat logika, sehingga hanya bisa dijalankan kalau emosi anak dalam keadaan tenang. Bila anak tertekan karena terus menerus terperangkap dalam situasi yang kacau, penganiayaan, dan pengabaian, maka input hanya sampai ke batang otak, sehingga sikap yang timbul hanya berdasarkan insting tanpa dipertimbangkan lebih dulu. Akibatnya anak berperilaku agresif; (4) Gangguan emosi, pada anak yang sering mendapatkan perlakuan yang salah dari orang tua akan berakibat gangguan emosi pada perkembangan konsep diri yang positif, dalam mengatasi sifat agresif, perkembangan hubungan sosial dengan orang lain, termasuk kemampuan untuk orang percaya diri. Selain itu juga terjadi pseudomaturitas emosi. Beberapa anak menjadi lebih agresif atau bermusuhan dengan orang dewasa, sedang yang lainnya menjadi menarik diri/ menjauhi pergaulan. Anak menjadi hiperaktif, perilaku aneh, kesulitan belajar, gagal sekolah, sulit tidur, dan tempertantrum; (5) Hubungan sosial, pada anak-anak ini sering kurang dapat bergaul dengan teman sebayanya atau dengan orangorang dewasa dan mempunyai teman sedikit, dan suka menganggu orang dewasa, misalnya dengan melempari batu, atau perbuatanperbuatan kriminal lainnnya; (6) Kepribadian sociopath atau antisocial personality disorder, dimana penyebab utama dari kepribadian ini adalah emotional child abuse yang dalam bentuk umumnya sering disebut juga dengan verbal abuse. Perilaku ini dapat terlihat dengan sering bolos, mencuri, bohong, bergaul dengan orang jahat, kejam pada binatang, dan prestasi sekolah yang buruk.

Akibat lain dalam jangka panjang yaitu anak yang mendapatkan kekerasan verbal akan melakukan hal yang sama dikelak kemudian hari terhadap anak-anaknya saat mereka menjadi orang tua. Karena esensinya anakanak merupakan peniru ulung. Maka rantai kekerasan itu akan terus berlanjut, dan kekerasan ini menjadi sebuah budaya dalam masyarakat (Needlman, 1998).

Menurut Soetjiningsih terdapat beberapa faktor yang mempengaruhi orang tua melakukan verbal abuse (Huraerah,2012), antara lain:

a) Faktor pengetahuan orang tua : Orang tua tidak mengetahui atau mengenal sedikit informasi mengenai kebutuhan perkembangan anak, misalnya usia anak belum memungkinkan untuk melakukan sesuatu tetapi karena sempitnya pengetahuan orang tua si anak dipaksa melakukan dan ketika memang belum mampu orang tua menjadi marah. Orang tua yang mempunyai harapan-harapan yang tidak realistik terhadap perilaku anak berperan memperbesar tindakan kekerasan pada anak. Serta kurangnya pengetahuan orang tua tentang pendidikan anak dan minimnya pengetahuan agama orang tua melatarbelakangi kekerasan pada anak karena orang tua kurang berpendidikan.

b) Faktor Pengalaman : Orang tua yang waktu kecilnya mendapat perlakuan salah merupakan situasi pencetus terjadinya kekerasan pada anak. Semua tindakan kepada anak-anak akan direkam dalam bawah sadar mereka dan akan dibawa sampai kepada masa dewasa, dan terus sepanjang hidupnya. Anak yang mendapat perlakuan kejam dari orang tuanya akan menjadi sangat agresif dan setelah menjadi orang tua akan berlaku kejam kepada anak-anaknya. Orang tua agresif melahirkan anak-anak yang agresif, yang pada gilirannya akan menjadi orang dewasa yang menjadi agresif. Gangguan mental (mental disorder) 
ada hubungannya dengan perlakuan buruk yang diterima manusia ketika dia masih kecil.

c) Faktor Keluarga : Faktor keluarga ini meliputi karakteristik anak, karakteristik orang tua dan keluarga. Karakteristik anak yang tidak diinginkan, lahir prematur, anak yang memiliki fisik berbeda (cacat), mental berbeda (retardasi mental), temperamen berbeda (sukar), tingkah laku berbeda (hiperaktif), dan anak angkat/ tiri berperan dalam orang tua melakukan kekerasan pada anaknya. Karakteristik orang tua dan keluarga yang juga turut berperan terhadap terjadinya kekerasan pada anak seperti; orang tua yang agresif dan impulsif, keluarga hanya dengan satu orang tua, orang tua yang dipaksa menikah saat belasan tahun sebelum siap secara emosional dan ekonomi, dan perkawinan dengan saling mencederai pasangannya dalam perselisihan.

d) Faktor ekonomi : Sebagian besar kekerasan dalam rumah tangga terjadi karena dipicu faktor kemiskinan, dan tekanan hidup atau tekanan ekonomi. Pengangguran, PHK, dan beban hidup lain kian memperparah kondisi. Faktor kemiskinan dan tekanan hidup yang semakin meningkat, disertai dengan kemarahan/kekecewaan pada pasangan karena ketidakberdayaan dalam mengatasi masalah ekonomi menyebabkan orang tua mudah sekali meluapkan emosi, kemarahan, kekecewaan dan ketidakmampuannya kepada orang terdekatnya. Anak sebagai makhluk lemah, rentan, dan dianggap milik orang tua, anak menjadi paling mudah menjadi sasaran. Kemiskinan sangat berhubungan dengan penyebab kekerasan pada anak karena bertambahnya jumlah krisis dalam hidupnya (misalnya, tidak bekerja atau berdesak-desakan) dan disebabkan mereka mempunyai jalan masuk terbatas kedalam sumber ekonomi atau sosial untuk mendukung selama waktu stress.

Faktor ekonomi ini juga meliputi ketimpangan sosial. Kita menemukan bahwa para pelaku juga korban kekerasan kebanyakan berasal dari kelompok sosial ekonomi yang rendah. Karena tekanan ekonomi, orang tua mengalami stress berkepanjangan. Ia menjadi sangat sensitif. Ia mudah marah. Kelelahan fisik tidak memberinya kesempatan untuk bercanda dengan anak-anak. Maka terjadilah kekerasan emosional. Pada saat tertentu orang tua bisa meradang dan membentak anak dihadapan banyak orang. Sehingga terjadilah kekerasan verbal.

e) Faktor sosial budaya : Faktor sosial budaya ini meliputi nilai atau norma yang ada dimasyarakat, hubungan antar manusia, kemajuan zaman yaitu pendidikan, hiburan, olah raga, kesehatan, dan hukum. Norma sosial mempengaruhi tindakan orang tua melakukan verbal abuse karena pada masyarakat tidak ada kontrol sosial pada tindakan kekerasan anak-anak. Sedang nilai-nilai sosial disini adalah dalam artian hubungan anak dengan orang dewasa berlaku seperti hierarki sosial di masyarakat. Atasan tidak boleh dibantah. Orang tua tentu saja wajib ditaati dengan sendirinya. Dalam hierarki seperti itu anak-anak berada dalam anak tangga terbawah. Mereka tidak punya hak apa pun. Orang dewasa dapat berlaku apa pun kepada anak-anak.

f) Faktor lingkungan : Faktor lingkungan juga mempengaruhi tindakan kekerasan pada anak. Lingkungan hidup dapat meningkatkan beban terhadap perawatan anak. Dan juga munculnya masalah lingkungan yang mendadak turut berperan untuk timbulnnya kekerasan verbal.

Komunikasi merupakan hal yang sangat penting dalam keluarga. Tanpa komunikasi yang baik antar anggota keluarga, bisa saja menimbulkan suatu kesalahpahaman. Steede (dalam Hanisah, 2005:5) mengatakan bahwa tanpa kemampuan komunikasi yang efektif, mungkin akan terjebak dalam adu konflik yang tak kunjung usai diantara orang tua dan anak. Oleh sebab itu sangat penting di dalam keluarga terjalin adanya komunikasi yang efektif agar anak mampu menceritakan segala permasalahan yang dihadapinya.

Widjaja (dalam Rahkmat, 2005:87) mengatakan bahwa kualitas komunikasi harus 
disertai dengan komunikasi yang efektif yakni apabila terjadi perubahan sikap, pendapat dan tingkah laku sesuai dengan yang diharapkan oleh komunikan. Sehingga keluarga yang memiliki komunikasi yang efektif diantara anggota keluarga diharapkan dapat memberikan kontribusi yang baik bagi perkembangan anak, baik dalam mengemukakan pendapat maupun penolakan terhadap orang lain secara baik dan benar.

Komunikasi yang efektif dalam keluarga dapat terjalin antara orang tua dan anak sehingga memberikan dampak positif bagi hubungan antara orang tua dan anak; karena adanya keterbukaan dan saling menghargai antara satu dengan yang lain. Apabila komunikasi yang efektif sudah terbentuk dalam keluarga maka semua yang dirasakan atau yang ingin disampaikan oleh anak akan tersalurkan. Pada akhirnya dengan terciptanya komunikasi yang efektif dalam keluarga kecenderungan perilaku negatif akan cenderung dapat dicegah.

Untuk dapat melihat kualitas komunikasi tentunya disertai dengan komunikasi antarpribadi yang efektif antara orang tua dan anak. Keakraban yang timbul antara orang tua dan anak dilihat pada ciri-ciri komunikasi yang efektif, yang dikemukakan oleh (Wiryanto, 2004), terdapat 4 indikator, yaitu : (1) Keterbukaan, adanya kemauan untuk membuka diri pada hal-hal tertentu, agar anak mampu mengetahui pendapat, gagasan atau pikiran kita sehingga komunikasi mudah dilakukan, (2) Sikap positif (Positiviness), Kecenderungan seseorang untuk memberikan suatu penilaian yang positif kepada orang lain, (3) Empaty, keadaan yang membuat diri seseorang dapat merasakan hal yang dirasakan oleh orang lain, (4) Sikap mendukung (Supportiveness), adanya sikap saling mendukung antara orang tua dan anak dalam tujuan agar pesan keduanya dapat tersampaikan dengan baik.

Baron dan Byrne (2005) mengatakan bahwa konformitas teman sebaya adalah suatu jenis pengaruh sosial dimana individu mengubah sikap dan tingkah laku individu agar sesuai dengan norma sosial kelompok. Konformitas adalah penyesuaian perilaku individu untuk menganut pada acuan norma kelompok, menerima ide atau aturan-aturan yang menunjukkan bagaimana individu tersebut berperilaku. Konformitas bergantungpada adanya orang yang selalu memperingatkan timbulnya keyakinan dan kebiasaan yang bertentangan di antara orang-orang disekitar. Santrock (2007) menambahkan bahwa konformitas terjadi saat individu mengadopsi sikap dan tingkah laku orang lain karena merasa adanya desakan,ini cenderung sangat kuat selama masa remaja. Sebab-akibat perilaku konformitas adalah campuran dari unsur-unsur yang berbeda yakni rasa ingin tahu dan lingkungan masyarakat di mana mereka tinggal, antara lain unsur-unsur ini mempengaruhi bagaimana remaja akan bereaksi dalam situasi sosial (McElhaney et al., 2008).

Konformitas muncul ketika individu meniru sikap atau tingkah laku orang lain dikarenakan tekanan dan kondisi lingkungan (Santrock, 2003). Sarwono (2002) menjabarkan konformitas sebagai bentuk perilaku yang sama dengan orang lain yang didorong oleh keinginan sendiri. Menurut Wall, dkk. (dalam Santrock, 2002) menyatakan bahwa konformitas teman sebaya pada masa remaja dapat bersifat positif ataupun negatif. Aspek-Aspek Konformitas Teman Sebaya, Sears, dkk (2005) menjelaskan bahwa aspek-aspek yang menjadi indikator dalam konformitas pada teman sebaya terdiri dari perilaku, penampilan, dan pandangan. Aspek tersebut dapat dijelaskan secara rinci sebagai berikut: (a) Kekompakan, Kekuatan yang dimiliki kelompok acuan menyebabkan remaja tertarik dan ingin tetap menjadi anggota kelompok. Eratnya hubungan remaja dengan kelompok acuan disebabkan perasaan suka antara anggota kelompok serta harapan memperoleh manfaat dari keanggotaannya, (b) Kesepakatan, Pendapat kelompok acuan yang sudah dibuat memiliki tekanan kuat sehingga remaja harus loyal dan menyesuaikan pendapatnya dengan pendapat kelompok, (c) Ketaatan, Tekanan atau tuntutan kelompok acuan pada remaja membuatnya rela 
melakukan tindakan walaupun remaja tidak menginginkannya. Bila ketaatannya tinggi maka konformitasnya akan tinggi juga.

Kartono (2003) agresi merupakan suatu ledakan emosi dan kemarahan hebat, perbuatanperbuatan yang menimbulkan permusuhan yang ditujukan kepada seseorang atau suatu benda. Hal sama juga menurut Atkinson (2000) menjelaskan agresi adalah perilaku yang secara sengaja maupun tidak sengaja bermaksud melukai orang lain (secara fisik atau verbal) atau menghancurkan harta benda. Menurut Myers (2012) menjelaskan bahwa agresif adalah perilaku fisik maupun perilaku verbal yang diniatkan untuk melukai objek yang menjadi sasaran agresif. Sedangkan menurut Mac Neil dan Stewart menjelaskan bahwa perilaku agresif adalah suatu perilaku atau suatu tindakan yang diniatkan untuk mendominasi atau berperilaku secara destruktif, melalui kekuatan verbal maupun kekuatan fisik, yang diarahkan kepada objek sasaran perilaku agresif. Objek sasaran perilaku meliputi lingkungan fisik, orang lain dan diri sendiri (Fattah,2010:80).

Perilaku agresif terjadi karena seseorang mengobservasi individu lain melakukannya baik secara langsung maupun tidak langsung. Bandura (1997) berpijak pada pemikiran bahwa perilaku seseorang adalah gabungan hasil faktorfaktor kognisi dan lingkungan. Keluarga dan teman sebaya adalah salah satu agen sosialisasi remaja. Banyak ahli yang mengungkapkan tipe agresivitas, diantaranya Buzz \& Perry (dalam Abd-El-Fattah, 2007:237) dengan membagi beberapa bentuk indikator agresivitas menjadi empat bagian yaitu: (a) Physical agression, yaitu tindakan Menyakiti,mengganggu, atau membahayakan orang lain melalui respon motorik dalam bentuk fisik, (b) Verbal agression, yaitu tindakan menyakiti,mengganggu, atau membahayakan orang lain melalui respon motorik dalam bentuk verbal, (c) Anger, merupakan suatu bentuk reaksi afektif berupa dorongan fisiologis sebagai tahap persiapan agresi. Beberapa bentuk anger adalah perasaan marah, kesal, sebal, dan bagaimana mengontrol hal tersebut, (d) Hostility, yaitu tergolong kedalam agresi covert (tidak kelihatan). Hostility mewakili komponen kognitif yang terdiri dari kebencian seperti cemburu dan iri terhadap orang lain, dan kecurigaan seperti adanya ketidakpercayaan, kekhawatiran.

\section{Metode Penelitian}

Desain penelitian ini berdasarkan jenisnya termasuk dalam penelitian kuantitatif. Teknik pengumpulan data menggunakan kuesioner, dengan sampel sebanyak 99 responden remaja di Kelurahan Simpang Tiga Pekanbaru melalui teknik random sampling. Untuk mengetahui pengaruh keempat variabel tersebut, penelitian ini menggunakan analisis regresi berganda.

\section{Hasil dan Pembahasan \\ 1. Pengaruh Komunikasi Verbal Abuse Orang Tua Terhadap Perilaku Agresif 2.}

Berdasarkan nilai koefisien determinasi atau R Square sebesar 0,575. Nilai R Square menunjukkan besarnya sumbangan variabel komunikasi verbal abuse orang tua terhadap perilaku agresif sebesar 57,5\% berada pada ketegori sedang, dimana besarnya sumbangan variabel lain yang mempengaruhi perilaku agresif diluar penelitian ini adalah sebesar 42,5 $\%$.

Berdasarkan hasil penghitungan, didapati $\mathrm{F}$ hitung sebesar 131,383 dengan signifikansi 0,000 . Oleh karena probabilitas $(0,000)$ jauh lebih kecil dari 0,05, maka model regresi dapat dipakai untuk memprediksi perilaku agresif.

Berdasarkan tabel dibawah, nilai konstanta (a) sebesar 7,878 dan koefisien variable komunikasi verbal abuse orang tua sebesar 0,568. Dengan demikian berdasarkan nilai konstanta dan koefisien regresi yang diperoleh, maka persamaan regresi pada penelitian ini adalah $\mathrm{Y}=$ $7,878+0,568 \mathrm{X}_{1}$.

Sementara itu nilai signifikansi variabel komunikasi verbal abuse orang tua lebih kecil dari $0,05(0,000<0,05)$ yang artinya $\mathrm{H} 1$ diterima 


\begin{tabular}{|c|c|c|c|c|c|c|}
\hline \multicolumn{7}{|c|}{ Tabel 1 Hasil Perhitungan Regresi Hipotesa 1} \\
\hline & \multirow[t]{2}{*}{ Model } & \multicolumn{2}{|c|}{$\begin{array}{c}\text { Unstandardized } \\
\text { Coefficients }\end{array}$} & \multirow{2}{*}{$\begin{array}{c}\text { Standardized } \\
\text { Coefficients } \\
\text { Beta } \\
\end{array}$} & \multirow[t]{2}{*}{$\mathrm{t}$} & \multirow[t]{2}{*}{ Sig. } \\
\hline & & $\mathrm{B}$ & Std. Error & & & \\
\hline \multirow[b]{2}{*}{1} & (Constant) & 7,878 & 1,809 & & 4,355 & 000 \\
\hline & $\begin{array}{l}\text { Komunikasi } \\
\text { Verbal Abuse }\end{array}$ & ,568 &, 050 & ,758 & 11,462 &, 000 \\
\hline & ependent Varia & rilaku & & & & \\
\hline
\end{tabular}

dan H0 ditolak yakni terdapat korelasi antara komunikasi verbal abuse orang tua terhadap perilaku agresif.

\section{Pengaruh Antara Kualitas Komunikasi Orang Tua Terhadap Perilaku Agresif}

Berdasarkan hail penghitungan nilai koefisien determinasi atau $\mathrm{R}$ Square sebesar 0,575 . Nilai $\mathrm{R}$ Square menunjukkan besarnya sumbangan variabel komunikasi verbal abuse orang tua terhadap perilaku agresif sebesar $57,5 \%$ berada pada ketegori sedang. Besarnya sumbangan variabel lain yang mempengaruhi perilaku agresif diluar penelitian ini adalah sebesar $42,5 \%$.

Hasil dari $\mathrm{F}$ hitung sebesar 131,383 dengan signifikansi 0,000 . Oleh karena probabilitas $(0,000)$ jauh lebih kecil dari 0,05 , maka model regresi dapat dipakai untuk memprediksi perilaku agresif.

Berdasarkan hasil penghtungan diperoeh nilai konstanta (a) sebesar 7,878 dan koefisien variable komunikasi verbal abuse orang tua sebesar 0,568. Dengan demikian berdasarkan nilai konstanta dan koefisien regresi yang diperoleh, maka persamaan regresi pada penelitian ini adalah $\mathrm{Y}=7,878+0,568 \mathrm{X}_{1}$. Sementara itu nilai signifikansi variabel komunikasi verbal abuse orang tua lebih kecil dari $0,05(0,000<0,05)$ yang artinya $\mathrm{H} 1$ diterima dan $\mathrm{H} 0$ ditolak yakni terdapat korelasi antara komunikasi verbal abuse orang tua terhadap perilaku agresif.

\section{Pengaruh Antara Konformitas Teman Sebaya Terhadap Perilaku Agresif}

Berdasarkan penghitungan dengan menggunalkan korelasi nilai koefisien determinasi atau R Square sebesar 0,677. Nilai $\mathrm{R}$ Square menunjukkan besarnya sumbangan variabel konformitas teman sebaya terhadap perilaku agresif sebesar $67,7 \%$ berada pada kategori kuat. Dan besarnya sumbangan variabel lain yang mempengaruhi perilaku agresif diluar penelitian ini adalah sebesar $32,3 \%$.

Berdasarkan penghitungan, nilai $\mathrm{F}$ hitung sebesar 203.566 dengan signifikansi 0,000. Oleh karena probabilitas $(0,000)$ jauh lebih kecil dari 0,05, maka model regresi dapat dipakai untuk memprediksi perilaku agresif.

Berdasarkan tabel dibawah, nilai konstanta (a) sebesar 5,295 dan koefisien variable konformitas teman sebaya sebesar 0,810 .

\begin{tabular}{|c|c|c|c|c|c|c|}
\hline \multicolumn{7}{|c|}{ Tabel 2 Hasil Perhitungan Regresi Hipotesa 2} \\
\hline \multirow{2}{*}{\multicolumn{2}{|c|}{ Model }} & \multicolumn{2}{|c|}{$\begin{array}{l}\text { Unstandardized } \\
\text { Coefficients }\end{array}$} & \multirow{2}{*}{$\begin{array}{c}\text { Standardized } \\
\text { Coefficients }\end{array}$} & \multirow[t]{2}{*}{$\mathrm{t}$} & \multirow[t]{2}{*}{ Sig. } \\
\hline & & $\mathrm{B}$ & Std. Error & & & \\
\hline \multirow[b]{2}{*}{1} & (Constant) & 7,878 & 1,809 & & 4,355 &, 000 \\
\hline & $\begin{array}{l}\text { Komunikasi } \\
\text { Verbal Abuse }\end{array}$ & ,568 & 050 & ,758 & 11,462 &, 000 \\
\hline \multicolumn{7}{|c|}{ a. Dependent Variable: Perilaku Agresif } \\
\hline
\end{tabular}


Dengan demikian berdasarkan nilai konstanta dan koefisien regresi yang diperoleh, maka persamaan regresi pada penelitian ini adalah $\mathrm{Y}=$ $5,295+0,810 \mathrm{X}_{3}$. Sementara itu nilai signifikansi variabel konformitas teman sebaya lebih kecil dari $0,05(0,000<0,05)$ yang artinya $\mathrm{H} 1$ diterima
$\%$ dengan kategori sedang. Sedangkan sisanya $52,2 \%$ dipengaruhi oleh variabel lain atau sebabsebab lain di luar dari variabel yang disebutkan dalam penelitian dan dalam model regresi ini.

Berdasarkan hasil penghitungan diketahui $\mathrm{F}_{\text {hitung }}$ sebesar 29,033 dengan signifikansi 0,000.

\begin{tabular}{|c|c|c|c|c|c|c|}
\hline \multicolumn{7}{|c|}{ Tabel 3 Hasil Perhitungan Regresi Hipotesa 3} \\
\hline \multirow{2}{*}{\multicolumn{2}{|c|}{ Model }} & \multicolumn{2}{|c|}{$\begin{array}{l}\text { Unstandardized } \\
\text { Coefficients }\end{array}$} & \multirow{2}{*}{$\begin{array}{c}\text { Standardized } \\
\text { Coefficients }\end{array}$} & \multirow[t]{2}{*}{$\mathrm{t}$} & \multirow[t]{2}{*}{ Sig. } \\
\hline & & $\mathrm{B}$ & Std. Error & & & \\
\hline \multirow[b]{2}{*}{1} & (Constant) & 5,295 & 1,636 & & 3,237 & 002 \\
\hline & $\begin{array}{l}\text { Konformitas } \\
\text { Teman Sebaya }\end{array}$ & 810 &, 057 & ,823 & 14,268 & 000 \\
\hline \multicolumn{7}{|c|}{ a. Dependent Variable: Perilaku Agresif } \\
\hline
\end{tabular}

dan H0 ditolak yakni terdapat korelasi antara konformitas teman sebaya terhadap perilaku agresif.

\section{Analisis Regresi berganda}

Adapun persamaan regresi linear berganda adalah :

$$
\mathrm{Y}=\mathrm{a}+\mathrm{b}_{1} \mathrm{X}_{1}+\mathrm{b}_{2} \mathrm{X}_{2}+\mathrm{b}_{3} \mathrm{X}_{3} \ldots . \mathrm{b}_{\mathrm{n}} \mathrm{X}_{\mathrm{n}}
$$

Pada uji determinasi $\left(\mathrm{R}^{2}\right)$ yang dilakukan untuk melihat berapa besar pengaruh yang diberikan variabel independen terhadap variabel dependen tampak pada tabel model summary diatas, bahwa diperoleh nilai $\mathrm{R}$ sebesar 0,692 dan nilai $\mathrm{R}$ Square sebesar 0,478 , artinya bahwa persentase pengaruh variable independen terhadap variable dependen adalah sebesar 47,8
Sedangkan nilai $\mathrm{F}_{\text {tabel }}$ dengan df $1=3$ dan df $2=95$ pada signifikansi $5 \%$ sebesar 2,700. Dengan demikian, maka diketahui $\mathrm{F}_{\text {hitung }}(29,033)>\mathrm{F}$ tabel $(2,700)$ atau Sig. $(0,000)<0,05$. Artinya H0 ditolak dan H1 diterima, bahwa variable independen secara bersama-sama berpengaruh signifikan terhadap variabel dependen.

Berdasarkan hasil dari coefficients ${ }^{\mathrm{a}}$ di bawah maka diperoleh persamaan regresi berganda sebagai berikut : $Y=0,866+0,342 X_{1}$ $+0,199 \mathrm{X}_{2}+0,235 \mathrm{X}_{3}$

Serta nilai koefisien regresi variabel konformintas teman sebaya sebesar 0,235. Artinya bahwa setiap peningkatan terhadap konformitas teman sebaya sebesar 1 satuan maka akan meningkatkan perilaku agresif sebesar

\begin{tabular}{|c|c|c|c|c|c|c|}
\hline \multicolumn{7}{|c|}{ Tabel 4 Hasil Perhitungan Regresi Ganda } \\
\hline \multicolumn{2}{|r|}{ Model } & \multicolumn{2}{|c|}{$\begin{array}{l}\text { Unstandardized } \\
\text { Coefficients }\end{array}$} & \multirow{2}{*}{$\begin{array}{c}\begin{array}{c}\text { Standardized } \\
\text { Coefficients }\end{array} \\
\text { Beta }\end{array}$} & \multirow[t]{2}{*}{$\mathrm{t}$} & \multirow[t]{2}{*}{ Sig. } \\
\hline & & $\mathrm{B}$ & Std. Error & & & \\
\hline \multirow{4}{*}{1} & (Constant) & .866 & .319 & & 2.714 & .008 \\
\hline & $\begin{array}{l}\text { Komunikasi Verbal } \\
\text { Abuse }\end{array}$ & .342 & .090 & .364 & 3.811 & .000 \\
\hline & Kualitas Komunikasi & .199 & .083 & .218 & 2.399 & .018 \\
\hline & $\begin{array}{l}\text { Konformitas Teman } \\
\text { Sebaya }\end{array}$ & .235 & .073 & .271 & 3.210 & .002 \\
\hline & ndent Variable: Peri & $\mathrm{Ag}$ & & & & \\
\hline
\end{tabular}




\section{0,235 dengan asumsi variabel lain tetap.}

Berdasarkan hasil penghitungan nilai $\mathrm{t}$ table pada taraf signifikansi 5\% (2-tailed) dengan $\mathrm{df}=95$ sebesar 1,985 . Maka diperoleh hasil dengan diketahui t hitung $(3,811)>\mathrm{t}$ tabel $(1,985)$ atau Sig. $(0,000)<0,05$. Sehingga dapat diambil keputusan bahwa $\mathrm{H} 1$ diterima dan Ho ditolak yakni komunikasi verbal abuse berpengaruh terhadap perilaku agresif. Kemudian diketahuinya $t$ hitung $(3,399)>\mathrm{t}$ tabel $(1,985)$ atau Sig. $(0,018)<0,05$. Sehingga dapat diambil keputusan bahwa $\mathrm{H} 1$ diterima dan Ho ditolak yakni kualitas komunikasi berpengaruh terhadap perilaku agresif. Serta diketahui $\mathrm{t}$ hitung $(3,210)>$ t tabel $(1,985)$ atau Sig. $(0,002)$ $<0,05$. Sehingga dapat diambil keputusan bahwa H1 diterima dan Ho ditolak yakni konformitas teman sebaya berpengaruh terhadap perilaku agresif.

Berdasarkan hasil perhitungan analisis data, maka informasi untuk menjawab hipotesis pada perumusan masalah secara objektif disajikan sebagai berikut :

Berdasarkan hasil analisa data pada penelitian ini menunjukkan bahwa terdapat adanya pengaruh komunikasi verbal abuse orang tua terhadap perilaku agresif. Temuan hasil penelitian ini sejalan dengan pendapat Bandura (1976, 256:260) mengatakan bahwa anak belajar tingkah laku agresif melalui model (peniruan), terutama dari orang tua, guru dan teman sebaya. Bandura juga mengatakan bahwa dalam masyarakat modern ada dua sumber munculnya perilaku agresif yaitu pengaruh lingkungan keluarga termasuk disini salah satunya pola asuh. Pettit dan Laird (2002), menemukan bahwa keterlibatan gaya pengasuhan penolakan atau parental rejection yang dilakukan orang tua yang kurang tepat akan membentuk proses kognisi individu dalam lingkungan keluarga tersebut, sehingga pembentukan kognisi individu tersebut akan merancang bagaimana perilaku yang akan dibentuk selanjutnya. Oleh karena itu perilaku agresif anak sangat tergantung pada cara orang tua memperlakukan (pola asuh) anaknya.

Kualitas komunikasi orang tua mempunyai pengaruh terhadap perilaku agresif. Menurut Bandura (dalam Dorothea Ross dan Sheila Ross (1961) bahwa perilaku agresif muncul sebagai akibat dari pengaruh lingkungan keluarga termasuk salah satunya kondisi komunikasi anggota keluarga (antara orang tua dan anak). Menurut Rakhmat (1996:257), setidaknya perilaku agresif mengandung adanya proses kognisi terhadap stimulus atau reaksi pada lingkungan.

Model stimulus - respon mengasumsikan bahwa kata-kata verbal (lisan-tulisan), isyaratisyarat nonverbal dan tindakan-tindakan tertentu akan merangsang orang lain untuk memberikan respon dengan cara tertentu, sehingga dimana proses ini dapat bersifat timbal-balik dan mempunyai banyak efek ap stumulus yang diberikan terhadap kondisi lingkungan. Dengan demikian setiap efek dapat mengubah tindakan komunikasi berikutnya. Dalam realitas pola ini dapat berlangsung negatif.

Serupa dengan yang dinyatakan oleh Clark dan Shields (dalam Lauer \& Lauer, 2000) bahwa kondisi lingkungan keluarga yang kurang memelihara komunikasi yang baik antara orang tua dan anak menunjukkan kenakalan yang tinggi dan terlibat pada perilaku menyimpang.

Berdasarkan hasil analisa data, menunjukkan bahwa terdapat pengaruh konformitas teman sebaya terhadap perilaku agresif. Dalam teori social learning bahwa perilaku agresif lebih banyak disebabkan oleh Tingkah laku diproduksi melalui proses belajar respon individu terhadap lingkungan yang diawali dari proses mengamati untuk pengambilan model dari lingkungan (Bandura, 1989). Dan juga dalam teorinya Bandura menggambarkan proses saling mempengaruhi antara individu dengan lingkungan (Bandura, dalam Wenar \& Kerig, 2005).

Konformitas munculketikaindividumeniru sikap ataupun tingkah laku orang atau kelompok dikarenakan tekanan yang nyata maupun yang dibayangkan oleh mereka (Santrock, 2003). Menurut (Ross, Bierbauer \& Stoffman, 1976) pada teori Social Comparison Theory, seseorang 
akan konform dengan kelompoknya karena ia menilai bahwa kelompok tersebut benar dan merasa takut untuk ditolak.

\section{Simpulan}

Berdasarkan hasil analisis data yang dilakukan, maka penelitian ini menyimpulkan bahwa terdapat pengaruh komunikasi verbal abuse orang tua terhadap perilaku agresif dengan kategori sedang. Dengan demikian setiap perubahan komunikasi verbal abuse orang tua pada anak sebesar satu satuan, akan diikuti peningkatan perilaku agresif sebesar 0,575 satuan. Terdapat pengaruh kualitas komunikasi orang tua terhadap perilaku agresif dengan kategori sedang. Maka setiap perubahan skor kualitas komunikasi orang tua pada anak sebesar satu satuan, akan diikuti peningkatan perilaku agresif sebesar 0,522 satuan. Terdapat pengaruh konformitas teman sebaya terhadap perilaku agresif dengan kategori kuat. Dengan demikian setiap perubahan skor konformitas teman sebaya sebesar satu satuan, akan diikuti peningkatan perilaku agresif sebesar 0,677 satuan.

Berdasarkan hasil penghitungan dengan regresi ganda diperoleh adanya pengaruh yang signifikan antara komunikasi verbal abuse orang tua, kualitas komunikasi orang tua dan konformitas teman sebaya secara bersama-sama terhadap perilaku agresif sebesar 0,478 dengan kategori sedang. Dengan demikian faktorfaktor dalam indikator komunikasi verbal abuse orang tua, kualitas komunikasi orang tua dan konformitas teman sebaya dapat mempengaruhi perilaku agresif. namun demikian indikator dari perilaku agresif yang paling dominan terdapat pada indikator physical agression dan anger. Oleh karena itu, model regresi dapat dipakai untuk memprediksi perilaku agresif.

\section{Daftar Pustaka}

Abd-El-Fattah, S.M. 2007. Is the Aggression Questionnaire bias free? A Rasch analysis. International Education Journal, 8(2), 237-248. Atkinson. 2000. Pengantar Psikologi edisi kesebelas jilid 2. Jakarta: Interaksara Bandura. 1997. Reflections on moral disengagement. In G. V. Caprara (Ed.), Bandura: A leader in psychology (pp. 23-41). Milano, Italy: Franco Angeli Baron, robert a., donn byrne. 2005. Psikologi sosial. Jakarta: Erlangga Berkowitz, leonard.2003.Emotional behavior (mengenali perilaku dan tindak kekerasan di Lingkungan sekitar kita dan cara penanggulangannya). Jakarta: PPM

Bush, A.H., \& Perry, M. (1992). The Aggression Questionnaire. Journal of Personality and Social Psychology, 63, 452-459

Chiazza, T. 2008. Influence Of Extracurricular Activities On Sexual Experiences During Adolescence : Pas Experience. ProQuest Dissertations \& Theses (PQDT), 1-73

Bandura, A., Dorothea Ross, dan Sheila A. Ross. (1961). "Transmission of Aggression through Imitation of Aggressive Models," Journal of Abnormal and Social Psychology, 63, 575-582

Fattah, Hanurawan. 2010. Psikologi Sosial. Bandung: Universitas Negeri Malang dan Remaja Rosdakarya.

Hanisah. 2005. Hubungan Komunikasi yang Efektif Antara Ibu dan Remaja Dengan Kecerdasan Emosional Pada Siswa. UIN SUSKA Riau. Kartono, K. 2003. Bimbingan Bagi Anak Dan Remaja Yang Bermasalah. Jakarta: Raja Wali Pers

Lauer, R. H, \& Lauer, J. C.2000. Marriage and family:The quest for intimacy (4th ed.). New York : McGraw-Hill McElhaney, K. B., Antonishak, J., \& Allen, J. P. (2008). "They like me, they like me not: Popularity and adolescents' perceptions of acceptance predicting social functioning over time. Child Development, 79(3), 720-731. doi :10.1111/j.1467-8624.2008.01153 Mu'tadin. 2004.Penyesuaian Diri Remaja. Bandung : PT Remaja Rosdakarya Myers, D. G. 2012. (a.b Aliya, Lala, Petty 
\& Putri). Psikologi Sosial.(edisi kesepuluh). Jakarta: Salemba Humanika

Nugroho, Agung. 2005. Strategi Jitu Memilih Metode Statistic Penelitian dengan SPSS. Yogyakarta: And

Rakhmat, 2005. Psikologi Komunikasi. Bandung: PT Remaja Rosdakarya

Rosenthal and Ambady. 1998. Non verbal Communication. USA: Academic .\&Hoffman,S., TheRoleofAttributio nProcessesinConformityandDissent. AmericanPsychologis, 1976,31,148-157

Santrock. 2003. Adolescence: Perkembangan Remaja (6 th Edition).Jakarta : Erlangga .2007. Adolescence Perkembangan Remaja edisi keenam.Jakarta: Erlangga Sarwono, S.W. 1984. Teori-teori Psikologi Sosial. Jakarta: Rajawali Pers

Sears, D. O., Feedman, J. L., dan Peplau, L. A. 2005. Social Psychology, 12th Edition. Pearson Education, Prentice Hal. Solihin Lianny. 2005. Kekerasan pada anak. Available from: URL: bpkpenabur.or.id
Tower-Crosson, C. 2005. Understanding child abuse and neglect (6thed). Boston: Alyn andBacon,PearsonEducationalCompany

Wenar \& Kerig. 2006. Developmental Psychopathology. 5th ed.Mc Graw Hill

Zebua, A.S \& Nurdjayadi, R.D. 2001. Hubungan antara Konformitas dan Konsep Diri dengan Perilaku Konsumtif pada Remaja Putri. Jurnal Phronesis.3.(6).72-82

h t t p s : / / m.te m p o c o / r e a d / news/2016/04/26/173765863/ kpai-kekerasan-terhadap-anakdi - indonesi a - m a s i h-t ing gi (Diakses pada 26 Desember 2016) Hadi, C. (2015, 12 30). GoRiau.com. Retrieved 11 08, 2016, from goriau.com:https:// www.goriau.com/berita/pekanbaru/wah5-kawasan-di-pekanbaru-ini-ternyatapaling-marak-terjadi-kejahatan.html (Diakses pada 26 Desember 2016) 